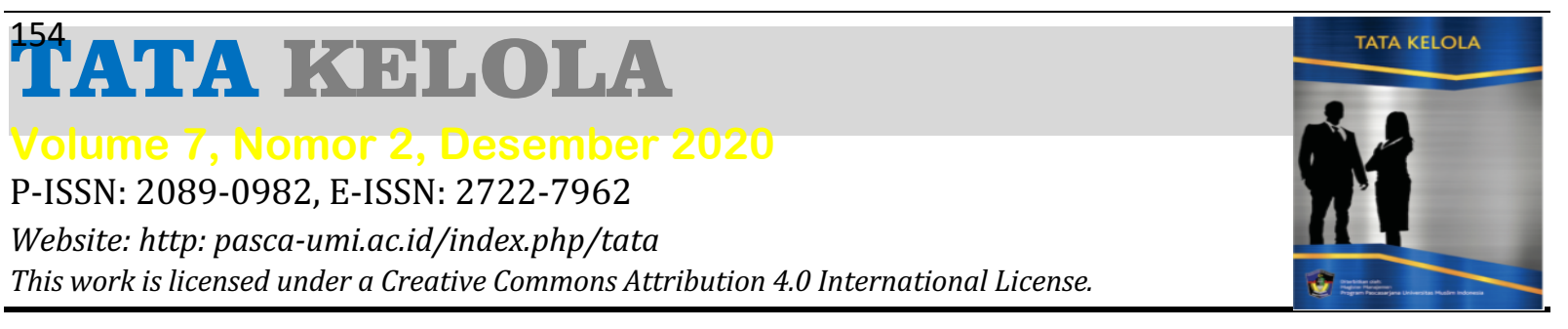

\title{
Pengaruh Pelayanan Sistem Informasi Akademik Terhadap Kinerja Operator Fakultas Ekonomi Dan Bisnis Islam UIN Alauddin Makassar
}

\author{
Fierda Amalia Hamzah 1, Masdar Mas'ud², Serlin Serang ${ }^{3}$ \\ ${ }^{1,2,3}$ Magister Manajemen, Universitas Muslim Indonesia. \\ ${ }^{1}$ Koresponden Penulis, E-mail: fierdaamaliahamzah@gmail.com
}

\begin{abstract}
ABSTRAK
Penelitian ini bertujuan untuk mengetahui 1) Untuk mengetahui bagaimana pengaruh pelayanan registrasi pembayaran terhadap penilaian kinerja operator Fakultas Ekonomi dan Bisnis Islam UIN Alauddin Makassar 2) Untuk mengetahui bagaimana pengaruh pelayanan kartu rencana studi terhadap penilaian kinerja operator Fakultas Ekonomi dan Bisnis Islam UIN Alauddin Makassar 3) Untuk mengetahui bagaimana pengaruh pelayanan penginputan absen terhadap penilaian kinerja operator Fakultas Ekonomi dan Bisnis Islam UIN Alauddin Makassar 4) Untuk mengetahui bagaimana pengaruh pelayanan kartu hasil studi terhadap penilaian kinerja operator Fakultas Ekonomi dan Bisnis Islam UIN Alauddin Makassar. Pendekatan penelitian yang digunakan adalah kuantitatif. Populasi dalam penelitian ini adalah seluruh mahasiswa Fakultas Ekonomi dan Bisnis Islam UIN Alauddin Makassar, berjumlah 2208 orang. Sampel adalah bagian dari jumlah dan karakteristik yang dimiliki oleh populasi tersebut. peneliti memilih sampel $10 \%$ dari total populasi yaitu sebesar 220 sampel. Metode analisis data yang digunakan adalah regresi sederhana.
\end{abstract}

Kata Kunci: Pelayanan, Sistem Informasi, Kinerja

\begin{abstract}
This study aims to determine 1) To determine how the effect of payment registration services on the performance appraisal of the operators of the Faculty of Economics and Islamic Business UIN Alauddin Makassar 2) To find out how the effect of study plan card services on the performance assessment of the operators of the Faculty of Economics and Islamic Business UIN Alauddin Makassar 3) To find out how the effect of the absent input service on the performance appraisal of the operators of the Faculty of Economics and Islamic Business UIN Alauddin Makassar 4) To find out how the effect of the study card service on the performance evaluation of the operators of the Faculty of Economics and Islamic Business UIN Alauddin Makassar. The research approach used is quantitative. The population in this study were all students of the Faculty of Economics and Islamic Business UIN Alauddin Makassar, totaling 2208 people. The sample is part of the number and characteristics of the population. The researcher chose a sample of $10 \%$ of the total population, namely 220 samples. The data analysis method used is simple regression.
\end{abstract}

Keywords: Services, Information Systems, Performance 


\section{PENDAHULUAN}

Perkembangan teknologi dan informasi dalam era globalisasi mengalami peningkatan yang sangat pesat. Perkembangan teknologi tidak hanya terjadi dalam satu aspek kehidupan manusia, melainkan terjadi perkembangan secara menyeluruh dalam aspek kehidupan. Salah satu aspek yang mengalami perkembangan secara pesat adalah perkembangan dalam aspek teknologi, terutama komputer. Dengan adanya perkembangan teknologi dapat memberikan sebuah keuntungan yaitu meningkatkan efisiensi dan efektivitas dalam hal pengolahan informasi.

Teknologi informasi, termasuk sistem informasi berbasis internet, yang memainkan peran penting dan terus berkembang dalam bidang bisnis ( $\mathrm{O}^{\prime}$ Brien dan Marakas, 2014). Teknologi informasi dapat membantu semua jenis bisnis dengan meningkatka efisiensi dan keefektifan proses bisnis, pengambilan keputusan manajerial, dan kerja sama kelompok kerja, yang memperkuat posisi kompetitif mereka dalam pasar yang dengan cepat tumbuh dan berubah. Manfaat ini diperoleh, baik ketika teknologi informasi digunakan untuk mendukung tim pengembangan produk, proses layanan pelanggan, transaksi perdagangan, atau kegiatan bisnis lainnya. Teknologi dan sistem informasi, secara sederhana merupakan sebuah bahan utama bagi keberhasilan bisnis dalam lingkungan global yang dinamis sekarang ini.

Keuntungan dari perkembangan teknologi dan informasi berdampak besar pada perguruan tinggi yang merupakan suatu wadah untuk meningkatkan mutu kualitas pendidikan bagi mahasiswa, dosen maupun pegawai. Menurut (Haag dan Keen, 1996) teknologi informasi adalah seperangkat alat yang membantu bekerja dalam hal mengolah informasi dan melakukan tugas-tugas yang berhubungan dengan pemrosesan informasi. Teknologi Perkembangan teknologi dan infomasi menuntut perguruan tinggi untuk dapat mengikuti arus perkembangan sehingga sudah menjadi keharusan bagi elemen-elemen yang terlibat dalam perguruan tinggi menguasai teknologi dan informasi terbaru. Dalam hal ini manajemen pengelolaan perguruan tinggi dituntut tidak lagi mengandalkan sistem kuno atau manual, melainkan menggunakan teknologi terbaru yang dapat berdampak efektif, efisien dan optimal dalam mengelola informasi yang ada.

Sistem informasi manajemen merupakan suatu sistem yang melakukan fungsi-fungsi untuk menyediakan data atau informasi yang dapat mempengaruhi semua operasi komputer. Pada dasarnya sistem informasi memiliki lima peran utama dalam organisasi, yaitu efisiensi, efektivitas, komunikasi, kolaborasi, dan kompetitif (Jogiyanto, 2003). Sistem informasi manajemen menyediakan data-data atau informasi untuk memenuhi kebutuhan manajerial, semua tingkat manajemen dan kebutuhan harian/rutin. Sebelum perangkat komputer ada, sistem informasi manajemen telah ada untuk memastikan pasokan data guna dimanfaatkan oleh manajer atau pengambil keputusan sehingga memungkinkan mereka untuk merencanakan dan mengendalikan operasional dari suatu organisasi atau perusahaan.

Secara teoritis, komputer sebagai perangkat pengolah informasi tidak selalu harus digunakan dalam sistem informasi manajemen, namun kenyataannya tidak mungkin sistem informasi yang kompleks dapat diolah tanpa menggunakan komputer dikarenakan keterbatasan sumber daya. (Turban, 1993) mengemukakan bahwa 
sistem informasi manajemen adalah sistem formal berbasis komputer untuk menyediakan informasi bagi pengambilan keputusan dalam sebuah Organisasi. Komputer telah menambahkan dimensi baru dalam hal pengolahan informasi, seperti kecepatan, ketelitian, meningkatnya volume data, dan adanya pertimbangan alternatif yang lebih banyak.

Perguruan tinggi sebagai salah satu organisasi pendidikan saat ini telah menerapkan teknologi informasi karena semakin kompleksnya masalah yang dihadapi. Universitas Islam Negeri Alauddin Makassar sebagai salah satu institusi pendidikan tinggi negeri di Makassar, dalam hal ini dinaungi oleh Kementrian Agama (Kemenag) merupakan salah satu kampus negeri yang didirikan untuk mencetak Sumber Daya Manusia (SDM) yang berkualitas sesuai dengan misi Negara Kesatuan Republik Indonesia. Sistem Informasi Akademik (SIAKA) telah diterapkan oleh UIN sejak tahun 2011 guna untuk mempermudah mahasiswa dalam hal memperoleh informasi.

Sistem Informasi Akademik (SIAKA) sangat membantu proses penyelenggaraan kegiatan akademik, dimana adanya tuntutan untuk kecepatan dan keakuratan informasi yang disediakan. Adapun hal-hal yang ditawarkan oleh SIAKA antara lain informasi Kartu Rencana Studi (KRS), Kartu Hasil Studi (KHS), Nilai, dan Penginputan absensi mahasiswa. Tak hanya dampak positif yang dirasakan oleh elemen yang terlibat dalam UIN Alauddin Makassar melainkan mereka juga turut merasakan beberapa kendala, seperti keterlambatan mahasiswa dalam mengisi Kartu Rencana Studi (KRS) tiap semester, kesulitan mahasiswa dalam mengontrol jadwal kuliah, dan jaringan yang membuat mahasiswa kesulitan untuk memperoleh informasi.

Berdasarkan fenomena yang telah diuraikan oleh penulis diatas, maka penulis tertarik untuk melakukan penelitian dengan mengangkat judul "Analisis Pengaruh Pelayanan Sistem Informasi Akademik Terhadap Kinerja Operator Fakultas Ekonomi dan Bisnis Islam UIN Alauddin Makassar".

Berdasarkan uraian tersebut, maka kerangka konseptual penelitian ini adalah:

\section{Gambar 1. Kerangka Konseptual}

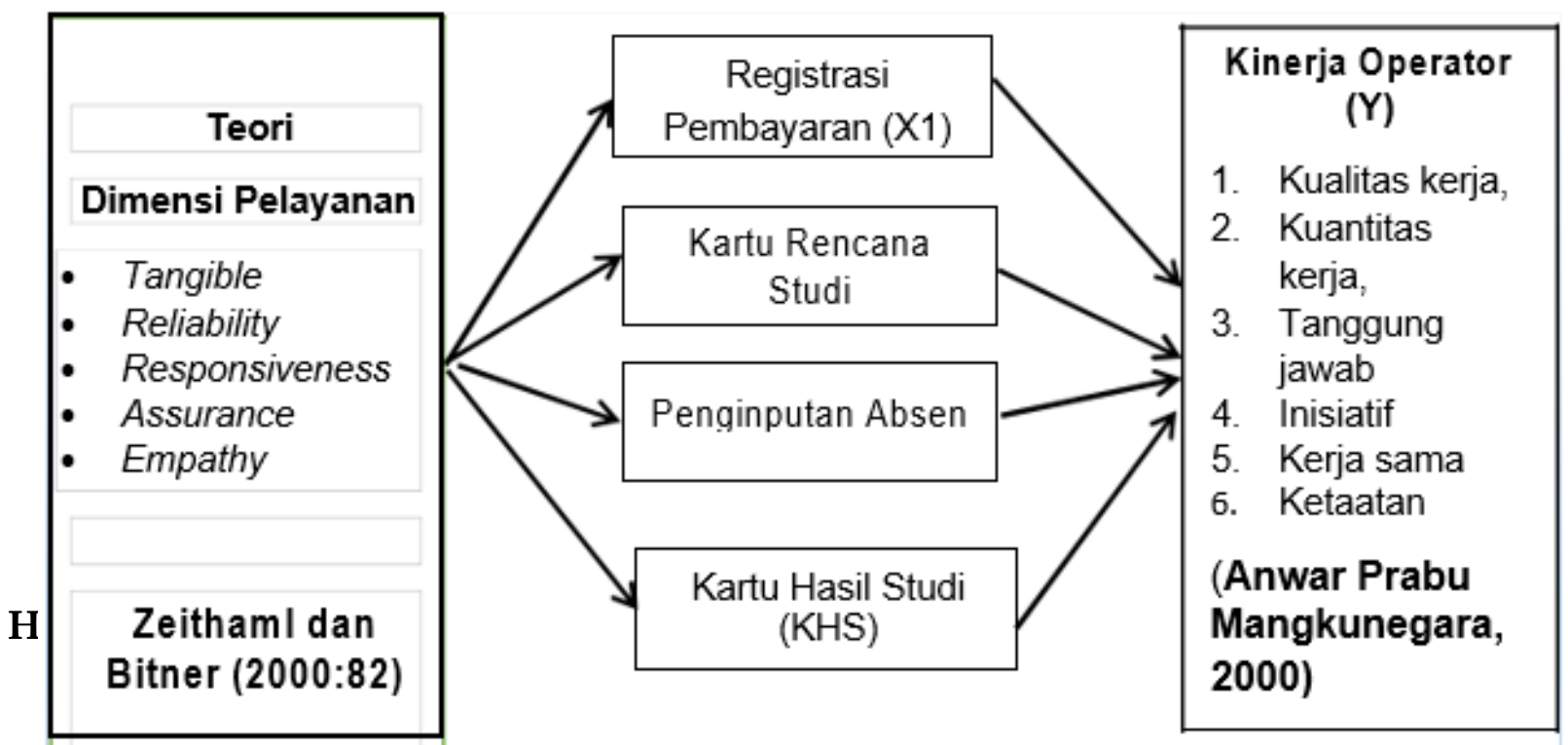


Berdasarkan latar belakang masalah dan kajian teori maka hipotesis dalam penelitian ini yaitu :

1. Pelayanan registrasi pembayaran berpengaruh terhadap penilaian kinerja operator Fakultas Ekonomi dan Bisnis Islam UIN Alauddin Makassar.

2 Pelayanan kartu rencana studi berpengaruh terhadap penilaian kinerja operator Fakultas Ekonomi dan Bisnis Islam UIN Alauddin Makassar.

3. Pelayanan penginputan absen berpengaruh terhadap penilaian kinerja operator Fakultas Ekonomi dan Bisnis Islam UIN Alauddin Makassar.

4. Pelayanan kartu hasil studi berpengaruh terhadap penilaian kinerja operator Fakultas Ekonomi dan Bisnis Islam UIN Alauddin Makassar

\section{METODE PENELITIAN}

Pendekatan penelitian yang digunakan adalah kuantitatif. Populasi dalam penelitian ini adalah seluruh mahasiswa Fakultas Ekonomi dan Bisnis Islam UIN Alauddin Makassar, berjumlah 2208 orang. Sampel adalah bagian dari jumlah dan karakteristik yang dimiliki oleh populasi tersebut. peneliti memilih sampel $10 \%$ dari total populasi yaitu sebesar 220 sampel . Metode analisis data yang digunakan adalah regresi berganda.

Penelitian dilakukan di Kota Makassar, Provinsi Sulawesi Selatan. Tepatnya pada UIN Aluddin Makassar yang beralamat di Jalan Sultan AlauddinPengujian.

\section{Hipotesis}

a. Uji Koefisien Determinasi $\left(\mathrm{R}^{2}\right)$

Nilai $R^{2}$ digunakan untuk mengukur seberapa jauh kemampuan model dalam menerangkan variasi variabel dependen. Pada penelitian ini yang digunakan adalah adjusted $\mathrm{R}^{2}$ dapat naik atau turun apabila satu variabel independen ditambahkan kedalam model. Nilai yang mendekati satu berarti variabelvariabel independen memberikan hamper semua informasi yang dibutuhkan untuk memprediksi variabel dependen (Ghozali, 2014)

b. Uji Regresi Simultan (Uji Statistik F)

Uji statistic F dilakukan dengan tujuan untuk menguji apakah keseluruhan variabel independen mempunyai pengaruh secara bersama-sama terhadap variabel dependen. Ghozali (2014:155). Pengujian simultan ini dilakukan dengan berpedoman pada hipotesis uji berikut:

$\mathrm{H}_{0} ; \beta_{\mathrm{I}}=0$ melawan $\mathrm{H}_{\mathrm{a}} ; \beta \neq 0$ Kriteria Pengujian :

Jika $F_{\text {hitung }}<F_{\text {tabel }}$ atau $\mathrm{P}>0,05$ maka $\mathrm{H}_{0}$ diterima Jika $\mathrm{F}_{\text {hitung }} \geq \mathrm{F}_{\text {tabel }}$ atau $\mathrm{P}<0,05$ maka $\mathrm{H}_{0}$ ditolak

Jika Ho diterima, berarti secara simultan, semua koefisien tidak berbeda nyata nilainya dengan 0 pada tingkat kepercayaan 95\%. Dengan demikian, hasil analisis regresi tidak dapat dipakai untuk melakukan pendugaan secara statistic, seperti membuat ramalan mengukur korelasi dan determinasi. Sebaliknya jika $\mathrm{H}_{0}$ ditolak, berarti secara simultan (bersama-sama) semua koefisien regresi berbeda nyata nilainya dengan 0 pada tingkat kepercayaan 95\%. Dengan demikian, hasil analisis regresi dapat dipakai untuk melakukan 
pendugaan secara statistic.

c. Uji t (Persial)

Untuk mengetahui ada tidaknya pengaruh variable bebas terhadap variable terikat, maka dilakukan pengujian hipotesis yang diajukan pada penelitian ini. Metode pengujian terhadap hipotesis yang dilakukan pengujian secara persial menggunakan uji t. uji $t$ menunjukkan seberapa jauh pengaruhnya variable independent.

Untuk menguji apakah masing-masing variable bebas berpengaruh secara signifikan terhadap variable terikat secara persial dengan menentukan derajat kepercayaan $95 \%(a=0,05)$ dan juga penerimaan atau penolakan hipotesis. Maka cara yang dilakukan adalah :

1) Ho : $b_{1}=0$, artinya variabel $X$ tidak mempunyai pengaruh yang signifikan secara persial terhadap variabel $Y$

2) Ha : $b_{1} \neq 0$, artinya variabel $X$ mempunyai pengaruh yang signifikan secara persial terhadap variabel $Y$

3) Taraf signifikan menggunakan 0.05

4) Dengan membandingkan $t$ hitung dengan table Apabila $t$ hitung $>t$ kritis Ho diterima, Apabila t hitung < $\mathrm{t}$ kritis Ho diterima.

\section{HASIL PENELITIAN DAN PEMBAHASAN}

\section{Hasil}

Hipotesis diuji dengan menggunakan uji signifikansi parameter individual ( Uji Parsial ). Uji ini digunakan untuk menguji tingkat signifikansi pengaruh variabel independen yang terdiri dari pemasaran digital melalui websites, social media dan email marketing terhadap variabel dependen yaitu peningkatan penjualan secara parsial atau secara sendiri-sendiri. Pengambilan keputusan dilakukan berdasarkan perbandingan nilai $t$ hitung masing-masing koefisien $t$ regresi dengan $t$ tabel sesuai dengan tingkat signifikansi yang digunakan yaitu 0,05. Hasil uji signifikansi parameter individual ( Uji t ) disajikan pada tabel berikut ini: 
Tabel 1. Persamaan Regresi

Coefficients $^{\mathrm{a}}$

\begin{tabular}{|c|c|c|c|c|c|c|}
\hline \multirow[t]{3}{*}{ Mode } & & \multicolumn{2}{|c|}{ Unstandardized Coefficients } & \multicolumn{3}{|l|}{ Standardized } \\
\hline & & \multicolumn{3}{|r|}{ Coefficients } & \multirow{2}{*}{$\mathbf{t}$} & \multirow[t]{2}{*}{ Sig. } \\
\hline & & $\mathbf{B}$ & Std. Error & Beta & & \\
\hline \multirow{5}{*}{1} & (Constant) & 9.157 & 1.721 & & 5.321 & .000 \\
\hline & Registrasi Pembayaran & .113 & .087 & .098 & 2.310 & .019 \\
\hline & Kartu Rencana Studi & .209 & .093 & .187 & 2.235 & .026 \\
\hline & Penginputan Absen & .014 & .073 & .016 & 2.186 & .028 \\
\hline & Kartu Hasil Studi & .070 & .070 & .067 & 2.400 & .032 \\
\hline
\end{tabular}

Sumber: Data diolah 2020

Persamaan regresi $Y=9.157+0.113 X 1+0.209 X 2+0.014 X 3+0.070 X 4$

Interpretasi data :

Nilai Konstanta 9.157 menunjukkan apabila registrasi pembayaran, kartu rencana studi, penginputan absen, dan kartu hasil studi konstan atau sama dengan Nol maka besarnya penilaian kinerja terhadap operator SIAKA sebesar 9.157 point.

Registrasi pembayaran dengan nilai koefisien regresi sama dengan 0.113 dengan tanda positif menunjukkan arah hubungan yang searah berarti setiap satu-satuan kenaikan pelayanan registrasi pembayaran akan meningkatkan penilaian kinerja terhadap operator SIAKA sebesar 0.113 point.

Kartu rencana studi dengan nilai koefisien sama dengan 0.219 dengan tanda positif menunjukkan arah hubungan yang searah berarti setiap satu-satuan kenaikan pelayanan kartu rencana studi akan meningkatkan penilaian kinerja terhadap operator SIAKA sebesar 0.219 point.

Penginputan absen dengan nilai koefisien sama dengan 0.014 dengan tanda positif menunjukkan arah hubungan yang searah berarti setiap satu-satuan kenaikan pelayanan penginputan absen akan meningkatkan penilaian kinerja terhadap operator SIAKA sebesar 0.014 point.

Kartu hasil studi dengan nilai koefisien sama dengan 0.070 dengan tanda positif menunjukkan arah hubungan yang searah berarti setiap satu-satuan kenaikan pelayanan kartu hasil studi akan meningkatkan penilaian kinerja terhadap operator SIAKA sebesar 0.070 point.

Analisis uji hipotesis dalam penelitian ini untuk membuktikan Hipotesis dalam penelitian ini yaitu: Pertama, Pengaruh pelayanan registrasi pembayaran terhadap 
penilaian kinerja operator Fakultas Ekonomi dan Bisnis Islam UIN Alauddin Makassar. Hasil uji hipotesis membuktikan nilai signifikasi pelayanan registrasi dengan nilai Sig sebesar 0,19 lebih kecil dari $a=0,05$ sehingga hipotesis yang menyatakan ada Pengaruh pelayanan registrasi pembayaran terhadap penilaian kinerja operator Fakultas Ekonomi dan Bisnis Islam UIN Alauddin Makassar terbukti. Kedua, Pengaruh pelayanan kartu rencana studi terhadap penilaian kinerja operator Fakultas Ekonomi dan Bisnis Islam UIN Alauddin Makassar. Hasil uji hipotesis membuktikan nilai signifikasi pelayanan kartu rencana studi dengan nilai Sig sebesar 0,26 lebih kecil dari $a=0,05$ sehingga hipotesis yang menyatakan ada Pengaruh pelayanan kartu rencana studi terhadap penilaian kinerja operator Fakultas Ekonomi dan Bisnis Islam UIN Alauddin Makassar terbukti. Ketiga, Pengaruh pelayanan penginputan absen terhadap penilaian kinerja operator Fakultas Ekonomi dan Bisnis Islam UIN Alauddin Makassar. Hasil uji hipotesis membuktikan nilai signifikasi pelayanan penginputan absen dengan nilai Sig sebesar 0,28 lebih kecil dari $a=0,05$ sehingga hipotesis yang menyatakan ada Pengaruh pelayanan penginputan absen terhadap penilaian kinerja operator Fakultas Ekonomi dan Bisnis Islam UIN Alauddin Makassar terbukti. Keempat, Pengaruh pelayanan kartu hasil studi terhadap penilaian kinerja operator Fakultas Ekonomi dan Bisnis Islam UIN Alauddin Makassar.

Tabel 2. Hasil Uji Regresi

\begin{tabular}{ccccc}
\multicolumn{6}{c}{ Model Summary } \\
\hline Model & R & R Square & $\begin{array}{c}\text { Adjusted R } \\
\text { Square }\end{array}$ & $\begin{array}{c}\text { Std. Error of the } \\
\text { Estimate }\end{array}$ \\
\hline 1 & $.930^{\mathrm{a}}$ & .864 & .798 & 2.256 \\
\hline
\end{tabular}

Nilai R Square $\left(R_{2}\right)$ sebesar 0,864 menunjukkan kemampuan variabel pelayanan sistem informasi akademik dalam menjelaskan kinerja operator Fakultas Ekonomi dan Bisnis Islam UIN Alauddin Makassar sebesar $86.4 \%$ sisanya 13.6 \% dijelaskan oleh variabel lain.

\section{Pembahasan}

Hasil uji hipotesis membuktikan nilai signifikasi pelayanan registrasi dengan nilai Sig sebesar 0,19 lebih kecil dari $a=0,05$ sehingga hipotesis yang menyatakan ada Pengaruh pelayanan registrasi pembayaran terhadap penilaian kinerja Aoperator Fakultas Ekonomi dan Bisnis Islam UIN Alauddin Makassar terbukti. Hasil penelitian ini sejalan dengan teori yang di ungkapkan oleh Milner (1990), Keberhasilan Pelayanan Informasi sangat berkaitan dengan Kinerja Operator dalam memberikan pelayanan, kinerja operator adalah bagaimana operator diharapkan dapat berfungsi dan berperilaku sesuai dengan tugas yang telah dibebankan kepadanya. Setiap harapan mengenai bagaimana operator harus berperilaku dalam melakukan tugas, berarti menunjukkan suatu peran dalam organisasi. 
Hasil uji hipotesis membuktikan nilai signifikasi pelayanan kartu rencana studi dengan nilai Sig sebesar 0,26 lebih kecil dari $a=0,05$ sehingga hipotesis yang menyatakan ada Pengaruh pelayanan kartu rencana studi terhadap penilaian kinerja operator Fakultas Ekonomi dan Bisnis Islam UIN Alauddin Makassar terbukti. Hasil penelitian ini mendukung pendapat (Indrayani, 2011) Bahwa Sistem Informasi manajemen kartu rencana studi ini dibangun untuk membantu mahasiswa dalam melakukan manajemen matakuliah yang diprogramkan.

Hasil uji hipotesis membuktikan nilai signifikasi pelayanan penginputan absen dengan nilai Sig sebesar 0,28 lebih kecil dari $a=0,05$ sehingga hipotesis yang menyatakan ada Pengaruh pelayanan penginputan absen terhadap penilaian kinerja operator Fakultas Ekonomi dan Bisnis Islam UIN Alauddin Makassar terbukti. Hasil penelitian ini sejalan dengan pendapat Sutabri (2012: 46) yang menyatakan bahwa "Sistem informasi pengimputan absen adalah suatu sistem didalam suatu organisasi yang mempertemukan kebutuhan pengolahan transaksi harian yang mendukung fungsi operasi organisasi yang bersifat manajerial dengan kegiatan strategi dari suatu organisasi untuk dapat menyediakan kepada pihak luar tertentu dengan laporan-laporan yang diperlukan. Demikian halnya dengan sitem pengimputan absen yang dapat dilakukan secara harian dan dapat diakses setiap saat oleh pengguna akun, sehingga memperlancar aksesbilitas penggunna dalam proses perekaman aktivitas kehadiran dan perkuliahan.

Hasil uji hipotesis membuktikan nilai signifikasi pelayanan kartu hasil studi dengan nilai Sig sebesar 0,32 lebih kecil dari $a=0,32$ sehingga hipotesis yang menyatakan ada Pengaruh pelayanan kartu hasil studi terhadap penilaian kinerja operator Fakultas Ekonomi dan Bisnis Islam UIN Alauddin Makassar terbukti. Hasil penelitian ini sejalan dengan pendapat Hansel Adrial Liyanto (2019) bahwa Aplikasi Pengelolaan Kartu Rencana dan Hasil Studi Mahasiswa Berbasis Web berfungsi untuk membantu kegiatan akademik seperti penyusunan KRS dan mengisi/melihat KHS secara online.

\section{KESIMPULAN}

Berdasarkan hasil penelitian dan pembahasan, maka dapat ditarik kesimpulan sebagai berikut: Pelayanan registrasi pembayaran berpengaruh terhadap penilaian kinerja operator Fakultas Ekonomi dan Bisnis Islam UIN Alauddin Makassar. Pelayanan kartu rencana studi berpengaruh terhadap penilaian kinerja operator Fakultas Ekonomi dan Bisnis Islam UIN Alauddin Makassar. Pelayanan penginputan absen berpengaruh terhadap penilaian kinerja operator Fakultas Ekonomi dan Bisnis Islam UIN Alauddin Makassar. Diduga pelayanan kartu hasil studi berpengaruh terhadap penilaian kinerja operator Fakultas Ekonomi dan Bisnis Islam UIN Alauddin Makassar.

\section{DAFTAR PUSTAKA}

Ghozali, I. (2014). Ekonometrika: Teori, Konsep Dan Aplikasi Dengan Ibm Spss 22. Semarang: Badan Penerbit Undip. 
Haag dan Keen. (1996). Information Technology: Tommorow's Advantage Today. Hammond: Meggraw-Hill Collage.

Jogiyanto. H. (2005). Sistem Teknologi Informasi. Penerbit: Andi, Yogyakarta.

Indrayani. (2011). Sistem Informasi Manajemen. Penerbit: Trans Info media, Jakarta.

O'Brien, J.A. dan Marakas. G.M. (2014). Sistem Informasi Manajemen: Pengantar Sistem Informasi. Penerbit: Salemba Empat, Jakarta.

Sugiyono. (2011). Metode Penelitian Kuantitatif, Kualitatif, R\&D. Penerbit: Alfabeta. Bandung.

Sutabri. (2012). Analisis Sistem Informasi. Penerbit: Andi, Yogyakarta.

Turban. E. (2001). Introduction to Information Technology. Penerbit: PT. Bina Ilmu. Jakarta. 